\title{
Vagn Lyhne
}

\section{Lægerne, maleren og de monomane}

„Géricault kom og besøgte mig den næste dag, onsdag. Jeg blev rystet over hans optræden: galskab! «

Eugéne Delacroix. Dagbog 16.maj 1823

I.

I årene omkring 1820 arbejdede den franske medicin intenst på at udforme en ny videnskabelig sjælelære, psykiatrien. Som $\mathrm{i}$ intet andet europæisk land havde kapitalismen i Frankrig banet sig vej over altomstyrtende, konvulsiviske rystelser, gennem en ubrudt kæde af dramatiske, blodige og storladne hændelser. Efter kejserdømmets sammenbrud, i nederlagets tusmørke, antog erobringskrigene skikkelse af nationalt forræderi, grusomt vanvid, der havde spredt hoveder, lemmer, kroppe af millioner af unge mænd hen over Europas store ligklæde. Så meget var tabt, så stor en udmattelse havde grebet det nye borgelige samfund, der uafviseligt var kommet for at blive. I overjordisk patos stillede de gamle besiddende klasser sig til rådighed for den nationale genrejsning og skred beslutsomt til værket: Restaurationen.

Det var en restauration, som defensivt bevægede sig mod en retablering af kongemagt, kirke, aristokrati og jordejendoms magt og position som før katastrofen i 1789, men som også offensivt stræbte mod udvikling af ny viden, nye midler til forståelse og intervention mod de nye menneskelige og sociale problemer, det kapitalistiske samfund allerede havde gjort synlige, påtrængende. For ejendommelige ting var under udvikling, ikke blot i samfundet, men i menneskene selv.

Så tidligt som 1793, midt i revolutionens kaos, havde lægen Philippe Pinel iagttaget en ny kategori afsindige, der ikke som de tidligere kendte var mærket og svækket på forstand, ræsonneringsevne og dømmekraft, 
men som under opretholdelse af deres fulde fornuft var hjemfaldne til voldelige og morderiske handlinger, udbrud af ødelæggelse og perversion. Ofte under indre heftig strid kastede de sig over selv deres kære, efter at de forgæves, for sent, havde søgt at advare dem om anfaldets komme. Flere af dem havde han observeret på sin anstalt Bicêtre, hvor de pludseligt, uvarslet faldt over deres medpatienter og vogtere med død og udslettelse som mål. Deres intelligens, forstand, hukommelse, sanseevne var intakte, deres følelser, passioner, tilbøjeligheder, drifter var syge. Denne nye art afsindighed kaldte Pinel manie sans délire. Disse syge var ikke som tidligere tiders gale let genkendelige, ravende rundt i afmægtig forvirring; de så ud og var uden for deres anfald som andre, men idet de $i$ ét nu rettede al deres kraft og forstand mod destruktion og død, udgjorde de den største trussel mod samfundet. ${ }^{1}$

Problemet med disse fornuftige afsindige voksede i omfang og alvor, for i 1819 kunne Pinels elev og arvtager Jean-Etienne-Dominique Esquirol forelægge sine observationer omkring en ny art vanvid, monomanien. Monomanien var, som ordet angiver, en afsindighed, der materialiserede sig på ét afgrænset område, en partiel forrykthed, der fandt sig veje under forstandens sikre ledelse. Men mens vanviddet med forstandsklarhed hos Pinel naivt var lænket til handlinger af stor og pludselig voldsomhed og grusomhed og ydermere først var blevet synliggjort, genstandsgjort for videnskabelig analyse af det revolutionære afsind selv, skaffede monomanien sig adgang til adfærdsformer, interaktioner, måder at tænke, føle og agere på, der var det borgerlige samfunds egne, selvfølgelige, nødvendige, hellige. Intet område syntes for ophøjet og ukrænkeligt, religionen, ægteskabet, forældrenes ømhed og børnenes pietet, fædrelandskrigen, købet og salget på markedet $\mathrm{i}$ alvor og lyst, venners festlige lag; intet for ubetydeligt, samlerens højtidelighed, når han efterabede skatmesteren, den tællendes iver, når han mumlede bogholderens kolonner, den renliges ildhu, når han tvættede sig på den nye borgerlige hygiejnes bud. Alle syntes de uden bestandigt forsvar mod den nye sygdom, alle kunne de gribes indefra for endeligt at perverteres.

Pinels manie sans delire tronede som drabsmonomani, ved dens højre hånd sad det futile, umættelige begær efter varer og genstande, kleptomanien, ved dens venstre den seksualitet, der havde revet sig løs fra ægteskab, troskab, og blu - nymfomanien og erotomanien. Nedad gik det mod alvorlige lidelser som pyromani, dipsomani, megalomani, dæmonomani, videre mod mere harmløse særheder, som privatborgeren var bærer af, tællemani, vaskemani, kværulantmani, samlermani, spillemani, undertiden holdt inden for socialt acceptable former, men altid truende 
bevægende sig mod undergangen i besættelse, forbrydelse. Men mens Pinels mordere og voldsmænd var menneskelige vilddyr, der snart gav sig til kende og kunne afsondres for samfundet for altid, var de monomane, som de bredte sig ud over samfundet, en lurende fare, en snigende gift, for selv for det $\emptyset$ vede blik var de yderst vanskelige at spore, forslagent havde de iført sig hver mands klædning. De kunne tale og skrive, konversere og arbejde med fornuft, og selv under langvarig observation nægtede den sygelige defekt af folelseslivet at afsløre sig. De lignede de andre, de mimede de andres tanker og handlinger, men dage og år tegnede det rids, der måtte udløse udskillelsen, for de ønskede brændende og dog alt for lidt. Som havde den uendelige længsel, digterne besang, omsider fundet sin skikkelse, var en umådelig lidenskab stivnet $i$ sit eget deforme, ensomme udtryk. Én ting ville de, om det så var med liv og borgerlig lykke som pris.

Båret af Esquirols mægtige autoritet blev monomanierne i de følgende årtier en formelig tvangstanke for de franske medicinere og psykiatere, og snart så også menigmand monomane overalt. Ganske heldigt for videnskaben blev offentligheden i begyndelsen af 1820 'erne opskræmt af en række gruopvækkende forbrydelser, begået med stor beslutsomhed og omtanke, men tilsyneladende savnende ethvert motiv. Blandt disse var en serie mord på tilfældige børn, præget af den mest oprørende og groteske automatisme, ligegyldighed og meningsløshed. Tilfældet Henriette Cornier var et af de mest publicerede og kommenterede, godt hjulpet af de uhyggelige omstændigheder $\mathrm{i}$ forbindelse med mordet, den list og forstillelse, hvormed det lykkes hende at få lov til at passe den lille Fanny et øjeblik, det lidenskabsløse snit, der skilte hovedet fra kroppen, blodet, der væltede fra spædbarnets torso og fyldte natpotten ved sengen, moderen, der kom for at hente sin lille pige og blev mødt med: Dit barn er død, hovedet, der blev kastet ud på gaden og trillede ned i rendestenen, hvor det var ved at blive knust under hjulene fra en vogn, faderen, der styrtede ud af sin butik og som det første så hovedet og samlede det op og kyssede og kærtegnede det. Og ikke blot kom sådanne uforklarlige mord i bølger, de fremkaldte nye mord, der aparte imiterede allerede begåede. Netop Henriette Coniers udåd truede med at udløse en sand epidemi.

I en række artikler i det indflydelsesrige tidsskrift Archives générales de Médicine analyserede den unge Etienne-Jean Georget et stort antal mord og retssager $\mathrm{i}$ et forsøg på endeligt at fastslå monomanierne som videnskabelig kendsgerning og med krav om, at lovgivning og domstole tilstod disse ulykkelige afsindige straffrihed og overgav dem til sindssygeanstalter- 
ne. Georget var det store håb i fransk psykiatri og havde allerede i 1820 som 25-årig udgivet den vigtige De la folie, der året efter blev fulgt af $D e$ la physiologie du système nerveux et spécialement du cerveau. Livfuld, brændende optaget af sit fag, manisk arbejdende og med en overlegen evne til at forarbejde store mængder kendsgerninger og give dem en ny, original formulering skrev han på disse år »to bind på den samme tid, som det ville tage for enhver anden at udtænke planen «, som det hedder i nekrologen. Som Géricault var Georget en af de unge døde. Han bukkede i 1828 under for lungetuberkulose efter i de sidste år også at have lidt af »hypokondri«, datidens betegnelse for paranoia. Forfølgelsesforestillingerne havde utvivlsomt en rationel basis, for Georget var fra 1820 under stadige angreb for materialisme og gudløshed, ligesom hans urbane, men hårde udfald mod justitsen blev besvaret skarpt og kløgtigt. ${ }^{2}$

De fem billeder af monomane, som Géricault udførte omkring 1822, var i Georgets eje. Det samme gælder fem andre billeder, der har indgået i serien. De er muligvis gået tabt, ihvertfald har de ikke kunne spores. Det er uvist om Géricault har været indlagt på Georgets afdeling på La Salpêtrière, der overvejende var en anstalt for kvinder. Men det synes sikkert, at billederne er malet på Georgets foranledning. Georget har antagelig henvendt sig til Géricault for at bede ham tilvejebringe fysiognomisk orienteret - illustrationsmateriale til en ny udgave af De la folie i lighed med det materiale, som allerede Johann Kasper Lavater og Charles Bell havde præsenteret, og i ædel kappestrid med Esquirol, der var ved at få udarbejdet plancher til sin bog Des maladies mentales. ${ }^{3}$ Men her var han kommet til den forkerte, for Géricault havde aldrig været til sinds at optrade som redskab for nogen. Hvorfor da i denne sag, der for ham var sagen selv. Her fandt han til sidst det motiv, hvori han mest fuldstændigt kunne give skikkelse til det liv, der var hans. For sagen selv er arbejdets og værkets sandhed, »er som gennemtrængning af virkeligheden og individualiteten enheden af disse 4.

II.

»At være fornuftig, føler jeg, bliver for hver dag mere min lod, uden at jeg dog af denne grund holder op med at være den mest forrykte af alle fornuftige, thi mit begær er stadig umætteligt...<

Brev til P.-J. Dedreux-Dorcy 12. februar 1821

Théodore Géricault (1791-1824) har i nogen grad stået i skyggen af 
Delacroix, der optager mange af de temaer, som Géricault først udarbejdede. ${ }^{5}$ I et kort liv brændte han sig op og efterlod sig dog en betragtelig produktion, der som den første i Frankrig afgørende bryder med de klassicistiske doktriner, og som i sit heftige udtryk er gennemstrømmet af en voldsomt potenseret individualitet, der sætter sig igennem, uanset omkostningerne. Udad strømmer denne livskraft $i$ kunstneriske udtryk, der mest har karakter af subversion, i tegning efter tegning, udkast, billeder, figurer, der gestalter stærke og muskuløse skikkelser, favnende hverandre i elskov, vold og død. Skræmmende opløses nøden, vanviddet og liderlighedens konturer for selvfølgeligt at antage én og samme skikkelse.

Kendtest er hans billeder »Rytterportræt af M.D...« eller »Bereden jægerofficer fra den kejserlige Garde foretager attak «, 1812, »Den sårede kyrassér«, 1814, og »Tømmerflåden fra Medusa «, 1819, alle ladet med historisk betydning: Gardens sidste kraftanstrengelse 1812, Nederlaget og endelig kannibalisme, blodbad, sult og vanvid på tømmerflåden efter »Medusas « forlis som sindbillede på den tilstand, en generation, en nation var efterladt $i$ efter $1815^{6}$ Mange af hans billeder viser heste, væddel $\varnothing b$, jockeys og boksekampe, for Géricault var som sin lærer, den vittige og indtagende Carle Vernet, sportsman og angloman, selv formuende, måske dandy, stærk, smidig og farlig som de løver og tigre, der optræder på hans billeder. Disse rovdyr var på ingen måde symbolske fremstillinger af den kapitalistiske entrepreneur eller børsmagnets færd gennem liberalismens jumgle, men gled drømmende over i den apparition og de færdigheder, der udmærkede de stærkeste og mest karismatiske medlemmer af society eller beau monde - adræthed, elegance, skønhed, ironi, wit. ${ }^{7}$ Andre billeder viser bevægende henrettelser, afhuggede hoveder, afsavede lemmer, smidt hulter til bulter i dissektionsstuerne eller forrådnende hjembragt fra hospitalet til kunstnerens atelier - nature morte, der bærer vidne om den nye tids ligegyldighed over for afsjælede legemer, kroppen som blot og bart studieobjekt og middel. Atter andre viser tiggere, blinde, lamme gået til bunds i storbyen London, og mennesker og dyr i arbejde, skildret i et formsprog, der gør Gericault til en vigtig forløber for Courbet og realismen. $\mathrm{Og}$ endelig selvportrætter, søgende, nådesløse, hallucinerede.

Géricaults liv vekslede tilsyneladende mellem perioder med uudtømmelig energi og inspiration og tider med dyb modløshed. »Tømmerflåden fra Medusa « blev malet $i$ en lykkelig periode, hvor han, efter at have lade sig kronrage for dermed at markere at fra nu af ville han ikke være at se i selskabet, isolerede sig i sit atelier for at koncentrere al sin 
kraft og lidenskab om værket. I 1819 berettes om anfald af forfølgelsesvanvid, og under et næsten toårigt ophold i England 1820-21 forsøgte han flere gange at begå selvmord. Han var ramt af, hvad datiden kaldte »den engelske syge «, spleen eller depression, en sygdom, der ifølge Georget var udløst af markedets feberagtige bevægelser, af lediggang, nydelser og sanseexcitation $i$ de nye storbyer. ${ }^{8}$ Den gamle melankoli trådte $i$ sin urbane klædning frem som spleen, og begge blev indordnet som former for monomani. For $i$ et dristigt forsøg på at tvinge den nye monomani igennem med vigtige samfundsmæssige konsekvenser hævdede Esquirol og efter ham Georget, at den gamle ærværdige melankoli underkastet en mere dybtgående videnskabelig undersøgelse og refleksion afslørede sig som den moderne tids monomani. ${ }^{9}$ Men mens næppe mange ville mistænke lægerne selv for at være monomane i deres intense, tålmodige udskillelse af objektet til analyse, klassifikation og behandling, var maleren i mange henseende deres lige, monoman som dem, selvmords-monoman, spleenetique.

\section{III.}

De monomane, der optræeder på Géricaults billeder, er ikke typer, der henter deres eksistens, deres liv, deres bestemmelser fra arten eller kategorien monoman. Disse mennesker ejer deres fulde individualitet, træeder frem $i$ deres udviklede historiske gestalt og griber netop i denne fuldt udarbejdede individualitet over i det almene, som først det borgerlige samfund kunne frembringe. Tilbagelagt er en Goyas eller en Hogarts fremstillinger af gale, der som sære og pittoreske menneskedyr vælter rundt imellem hinanden på anstalterne, Charles Bells truende, jættestærke urtidsmænd i lænker. Gennemtrængt af kærlighed til det, der var mest hans eget, bærer Géricaults portrætter anklage og hån mod de typiserende grafiske og fotografiske illustrationer, der skulle begejstre lægerne og publikum op gennem århundredet, og lader det tab af humanitet se, der aldrig siden skulle forvindes.

De fem bevarede billeder i Géricaults serie viser alle personer malet på en mørk baggrund, fremstillet $\mathrm{i}$ den for Gericault karakteristiske bevægeligt-transformerende clair-obscur teknik. I et øjeblik bevæger de sig ud af mørket og fanges i lyset, inden de glider tilbage i mørket for altid. De tre mænd er alle behersket af lidenskaber, der vil drive dem mod forbrydelsen.

Oldingen skæver til siden, betydningsfyldt drømmende om Napoleons- 
krigenes storhed, om felttog og slag under hans højstegne feltherrekommando, kejserlige travesti, vraggods fra besættende længsler drevet ind på anstalten her. På brystet hænger et bybudsskilt med nummeret 121, nummeret på det kompagni, han anfører og opildner, nummeret på den celle, der blev hans løn.

Kleptomanen lettere forpjusket, men endnu elegant, smukke øjne, det ene større end det andet, belyst og lysende afsøger det rummet, for mennesker, for ting. Skinnende varer i glitrende butikker, bazarer, passager råber ham an, fortryllet kærtegner han genstande, der hastigt gled ind under frakken for umærkeligt at gribes af lede, når først han har nået sin bolig. Ligegyldigt kaster han dem fra sig i bunken i hjørnet, snart må han atter afsted.

Børnevennen står langt fra sine små, panden tårnhøj under baretten, ville dog blot være sammen med børnene lidt, købe dem bon-bon'er og sjove presenter, høre latter fra liv, der længst er gledet bort. Kikker sørgmodigt derfra, længes mod dette, det ene.

Den spillegale kvinde glaner enfoldigt, munden som en skuffe fuld af savl. Triste dage, alderdom og ensomhed oplivet af lidt selskab om terninger, kortspil, krykken svinger, eller følger hun hypnotiseret nationallotteriets store hemmelighedsfulde bevægelse, der i et nu vil bade hendes liv i lykke?

Og ildevarslende er kvinden, der lider af misundelsesmonomani, af en eftertid kaldet »hyænen fra Salpêtrière. " For mens de andres vanvid er bundet til en bestemt genstand, er hendes monomani kun monomani på skrømt, ubestemt truende breder det sig ud som grænseløst savn af liv, der er i andres eje. Heftigt må hendes nag have været, voldsom hendes vrede, før samfundet har taget skridt til hendes indespærring. Med højre øje halvt tillukket, borende blik, munden spidsende sig som fuglens næb, der snart vil snappe, synes hun beredt til handling, fikserende en genstand blandt genstande i et tab uden ende. Højtidsfulde, alvorlige, grundende fortæller disse monomane om historisk formet begær, om længsler og savn udviklet i livsforløb, der unddrager sig fysiognomikkens og psykiatriens snævre kategoriseringer, om fortryllelsen fra vareverdenen, fascinationen af den militære magt og pomp, om den nye kærlighed til barnet, der endnu ikke har fundet sin form, og om lysten, der rugende strejfer om fra mål til mål.

Ene står de i mørket. Men i rummet er endnu en til stede, den, der iagttager og maler, Géricault selv. I et selvportræt, malet da han var 1718 år, har han gjort sig selv til genstand for observation i et lignende tomrum. Sidste skrig, sort kjole, fadermordere, det kunstfærdigt bundne, 


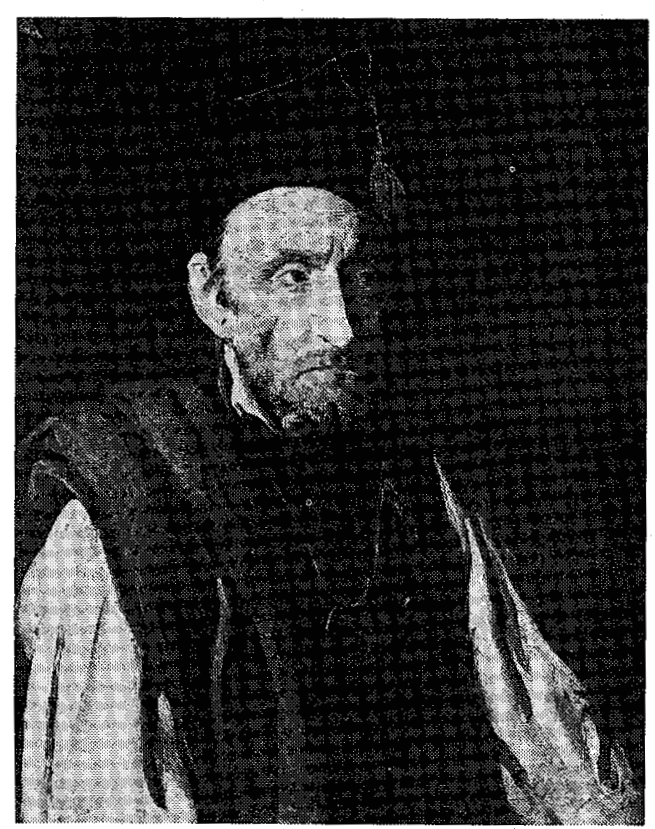

Feltherremonomani

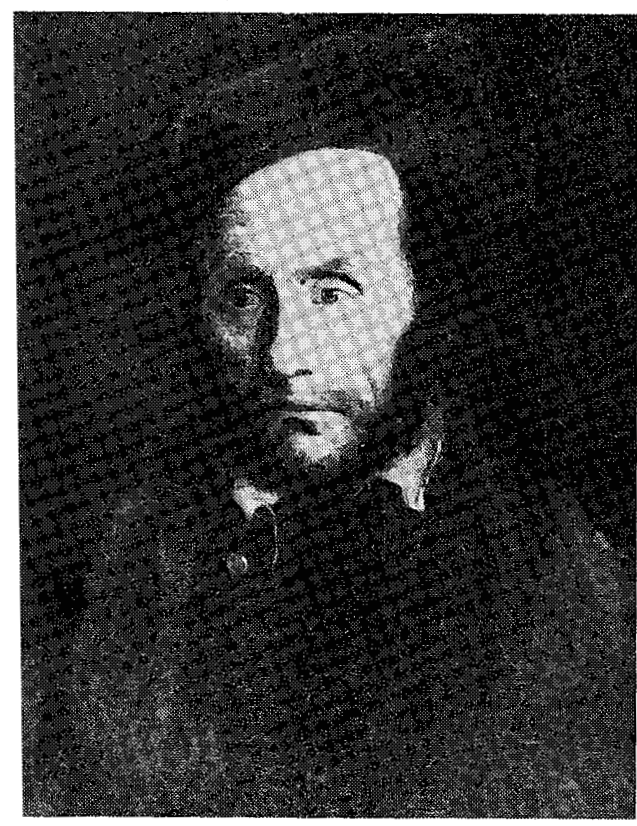

Kidnapningsmonomani

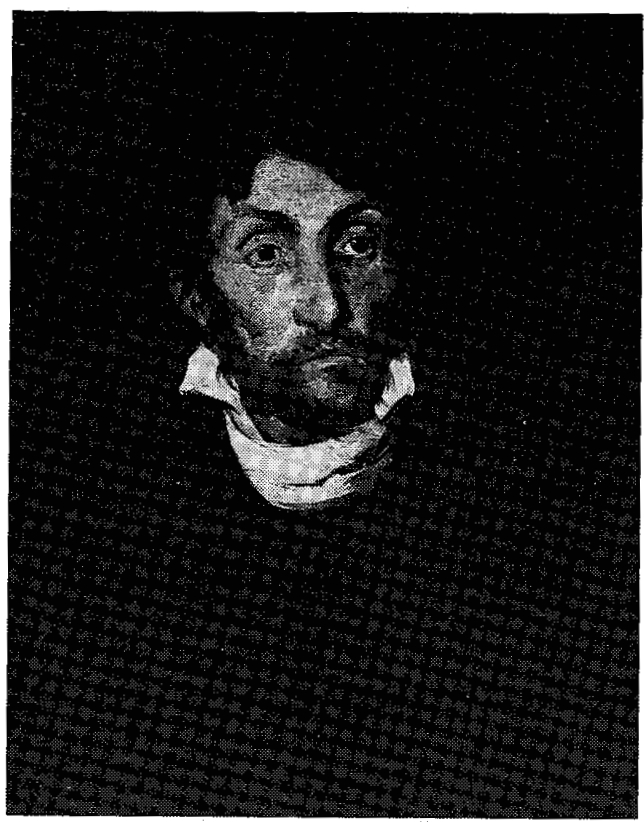

Kleptomani

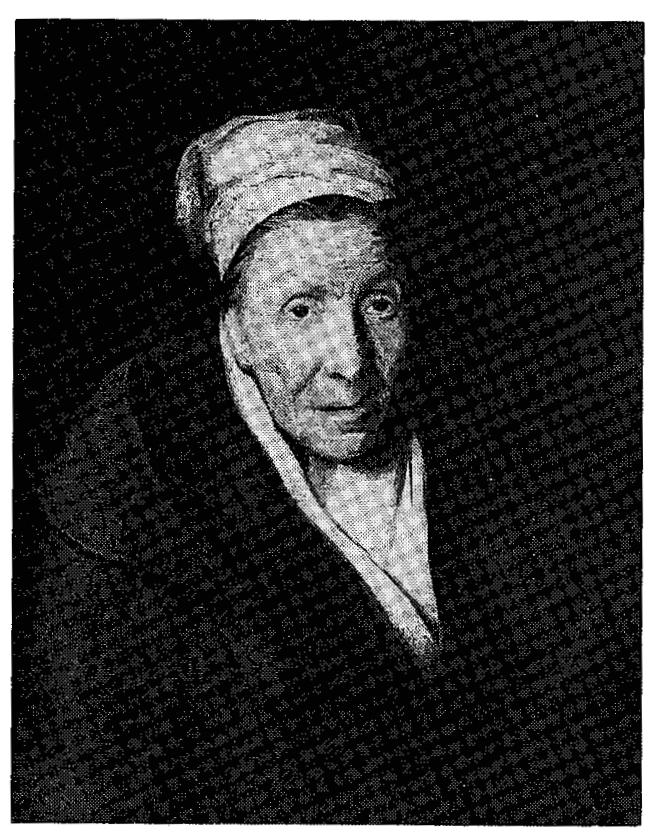

Spillemani 
kridhvide halsbind over kalvekrøset, klædt til fest løfter han selvbevidst de pensler, der nu vil føje ham i udførelsen af værket. Den røde mund, de rosa kinder, det blottede øre, det tykke, friserede hår, de kraftige øjenbryn over øjnene, mandelformede, skæve, det hovmodige, hånlige ansigtsudtryk, alt varsler ulykke, vidner om en eksaltation, en drift, et håb, der aldrig vil kunne rummes inden for det borgerlige liv. Denne unge mands ansigt er alt for levende og griber i sin tøjlesløse ekspression efter døden.

\section{IV.}

Januar 1848. Om få uger vil revolutionen gå hen over Europa. Jules Michelet skriver på sin femte forelæsning. På væggen $\mathrm{i}$ hans værelse hænger Géricaults dødsmaske. Ikke derfor, men fordi han øjner Géricault i den lange kæde af levende og døde, der langsomt drager sig hen imod det, der skal komme, skriver han:

»Omkring 1823 fandt der ved indgangen til operaballet en bedrøvet samtale sted... mellem en af mine venner, verdensmand, uendelig spirituel kunstner, og en ung mand, en stor mand, der var ramt i sit hjerte, og som syntes at søge at fremskynde dødens komme gennem sanselige nydelser... Min ven mødte ham meget sørgmodig midt i den muntre skare: kvinderne i deres smukkeste balklæder, vognene, lysene; han selv var i stort toilette, gule handsker, men allerede meget forandret. Hans magtfulde bliks uendelige blidhed var veget for det bitre udtryk i den frygtelige maske, De alle har beundret. Det udtrykte stadig geni, men var ikke længere kraftens udtryk, snarere en dødelig lidenskab efter at gribe denne flygtige verden, og $\mathrm{i}$ den dybe øjenhule falkens vilde blik.

Min ven, der holdt af ham, som $\mathrm{i}$ ham så Frankrig og kunsten $\mathrm{i}$ deres højeste udtryk, forsøgte at standse ham på dette sted, tiggede og bønfaldt... Forgæves. Trist, mørk, kastede han sig ned i den tindrende malstrøm...

Jeg taler om dette århundredes største maler, om den ulykkelige Géricault. ${ }^{10}$ 


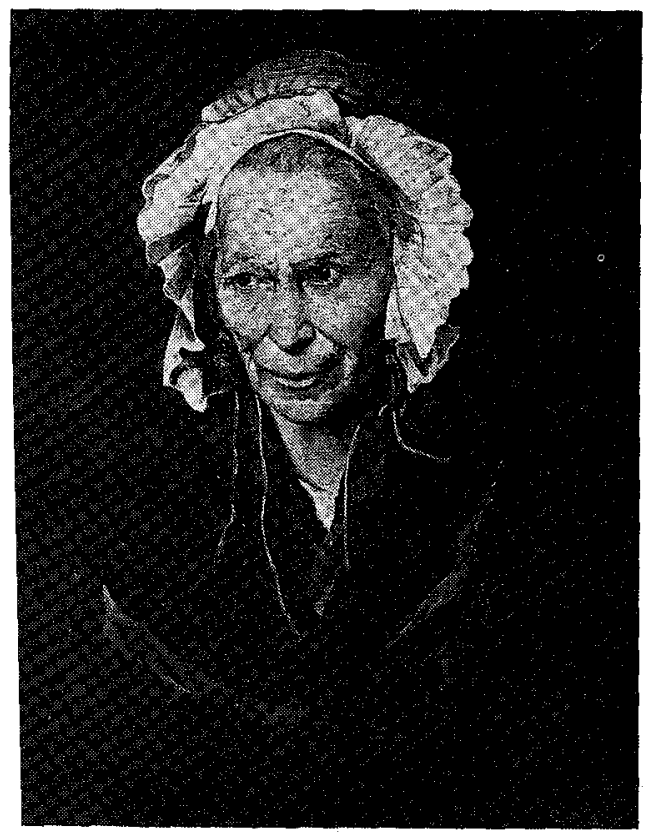

Misundelsesmonomani

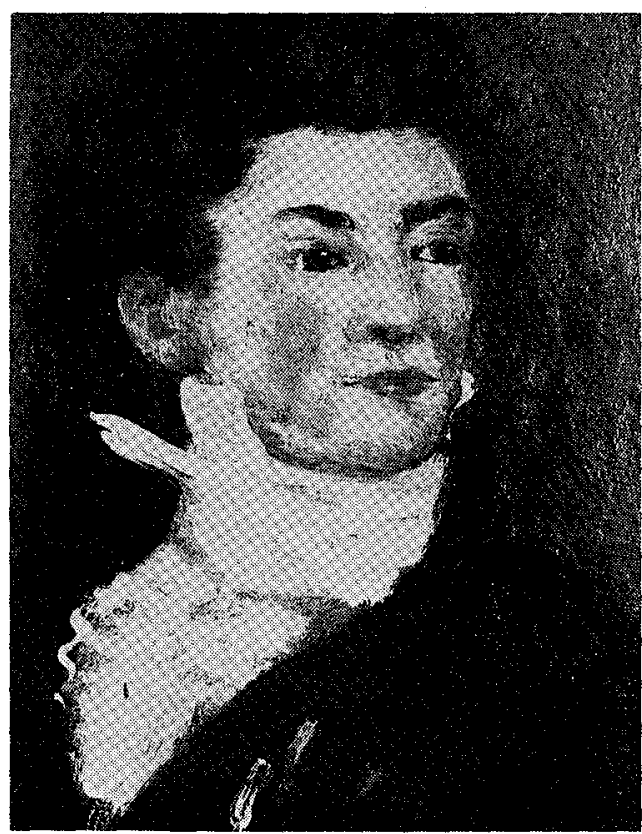

Selvportrat

Noter

Det grundlæggende arbejde om Géricault er Charles Clémemt's Géricault, der oprindeligt fremkom som artikelserie i Gazette des Beaux-Arts 1867, samme år udgivet som selvstændig publikation. Det lykkedes Clément at opstille en kommenteret fortegnelse over Géricaults værker, der var spredt for alle vinde. Alle senere arbejder bygger på de oplysninger, som Clément fik samlet, blandt andet fra personer, der havde kendt Géricault. Cléments artikler ejer den friskhed, som nærheden til personer og begivenheder giver og gennemstrømmes af pionerens glæde ved at afmærke et territorium. Til denne artikel er, hvad maleren selv angår, især benyttet Lorenz Eitner: Géricault. His Life and his Work, London 1983. Endvidere Léon Rosenthal: Géricault, Paris 1905 og Klaus Berger: Géricault und sein Werk, Wien 1952. Til billederne af de monomane Margaret Miller's grundige og vederhæftige "Gericault's Paitings of the Insane «, Joumal of the Warburg and Courtauld Institutes, Vol.4., London 1941, pp.151-163. Vigtige psykiatrihistoriske fremstillinger er Michel Foucault's to smukke bøger om anstalter og fængsler m.m.m., Klaus Dörner's lærde Frankfurter-monster: Bürger und Irre, Frankfurt a.M. 1969 og en mindre kendt, Robert Castel's velskrevne og veldokumenterede: L'ordre psychiatrique. L'âge d'or de l'aliénisme, Paris 1976. Men generelt kan det anbefales at læse de gamle sjælelæger selv, for hvad psykiatrihistorikere ofte destillerer til ukendelighed, havde de for vane at sige lige ud, involveret $\mathrm{i}$ bestandige fejder, som de var. 
1. "Man kan med rette beundre Lockes skrifter og dog alligevel erkende, at de antagelser, som han har om galskab, er meget ufuldstændige, idet han anser den for uadskillelig fra forstandsforvirring. Jeg tænkte selv som denne forfatter, da jeg på Bicêtre genoptog min udforskning at denne sygdom, og jeg var ikke så lidt overrasket over at se adskillige afsindige, som på intet tidspunkt frembød nogen beskadigelse af forstanden, og som var behersket af en art raseriets instinkt, som om kun de affektive kræfter var blevet beskadiget... Galskab uden forstandsforvirring har givet anledning til et enestående optrin i en fase af revolutionen, som man gerne ville slette ud af vores historie. Under fængselsmassakrerne skaffede banditterne sig under dække af at være forrykte adgang til anstalten for afsindige Bicêtre under påskud af at ville befri visse ofre for det gamle tyranni, som dette havde søgt at lade indgå blandt de afsindige; bevæbnede går de fra aflukke til aflukke; de udspørger de indsatte, og de går videre, hvis afsindigheden er åbenbar. Men en af de indespærrede, der er lagt i lænker, tiltrækker deres opmærksomhed ved at tale fuld af forstand og fornuft og ved de bitreste klager. Var det ikke skændigt, at man holdt ham i jern, og at man blandede ham sammen med de andre, der var afsindige? Han benægtede, at man kunne bebrejde ham den ringeste urimelighed; det var, tilføjede han, den mest oprørende uretfærdighed. Han anråber disse fremmede om at bringe en sådan undertrykkelse til ophør og om at blive hans befriere. Fra nu af rejser der sig i denne bevæbnede bande en heftig vredesmumlen og skrig af forbandelse mod forstanderen for anstalten; man tvinger ham til at komme og aflægge regnskab for sin handlemåde, og alle sabler er rettet mod hans bryst; man anklager ham for at gøre sig til redskab for de mest oprørende overgreb, og man byder ham først at tie, da han vil retfærdiggøre sig: han påberåber sig forgæves sin egen erfaring og opregner andre eksempler på lignende afsindige, der på ingen måde er $\mathrm{i}$ vildelse, men som er meget farlige på grund af et blindt raseri: man svarer med skældsord, og havde hans hustru ikke udvist stort mod ved så at sige at dække ham med sit legeme, ville han adskillige gange været segnet gennemboret af st $\varnothing \mathrm{d}$. Man beordrer, at den afsindige skal befries, og man fører ham derfra under forstærkede råb: vive la République! Synet af så mange bevæbnede mænd, deres støjende og forvirrende tale, deres ansigter blussende af vindunster, vækker den afsindiges raseri; han griber med en kraftfuld arm mod sin sidemands sabel, og hvis det ikke omgående var lykkedes at gøre sig til herre over ham, ville han denne gang have hævnet den krænkede menneskehed. Den barbariske horde forer ham til hans indelukke og synes rødmende at vige for retfærdigheden og erfaringens røst.« - Philippe Pinel: Traité médico-philosophique sur l'aliénation mentale ou la manie, Paris an IX (1801), pp.149-50 \& 153-55 (ed. Slatkine 1980).

2. Georget blev optaget som søn i Esquirols hus, og han døde i sin lærers arme. Georget gik i sin materialisme, hvor han lægger sig tæt op ad hjerneanatomiens egentlige grundlægger, frenologen Franz Joseph Gall, meget for vidt i forhold til de strømninger, der beherskede Restaurationen. I sine sidste år 
skrev han et åndeligt testamente og indrømmede Gud og Sjælen den plads, der tilkommer dem. Han ønskede, at dette testamente efter hans død skulle få den videst mulige udbredelse, hvilket det bl.a. fik gennem den udførlige, kærlige og anerkendende biografi, Esquirol skrev til Michaud's Biographie Universelle. Georgets artikelserie i Archives générales de Médicine er et retspsykiatrisk mesterværk, skrevet med klarhed, dynamik og taktisk forståelse. Men også her gik han, selv om han klogt indrømmede flere af de anklagede og dømte i besiddelse af tilregnelighed og viljens frihed, for vidt. Reflekterende kritiske formuleringer, der fra juridisk hold direkte var blevet rettet mod Georget, skriver Esquirol i sin afhandling »Mémoire sur la monomanie homocide « 1827: „Gud forbyde, at vi som forfægtere af materialisme og fatalisme skulle udtænke og forsvare teorier, der er omstyrtende for moralen, samfundet og religionen. Vi har ikke til hensigt at gøre os til forsvarere for misgerningen og forvandle de store forbrydelser til anfald af galskab; men vi mener, at doktrinen om monomanien er noget andet end forbrydelsen, der undskylder forbrydelsen « (cit. efter Castel, op.cit., p.180).

3. Alexander Morison besøgte i 1818 Esquirol og skriver i sin dagbog: „Han har næsten 200 gipsafstøbninger af afsindige personers ansigter og 600 hovedskaller « (Eitner, op.cit., p.354). Morison udgav i 1843 Physiognomy of Mental Diseases, forsynet med mange instruktive litografier.

4. G.W.F Hegel: Werke Bd.3, Phänomenologie des Geistes, Frankfurt a.M. 1970, p.304.

5. Delacroix fik lov til at sidde model til en af figurerne p̊̊ » Tømmerflåden fra Medusa . Og til at male et religiøst billede, som Géricault havde fået $\mathrm{i}$ bestilling som en trøstepræmie efter Salonen 1819, hvor staten ikke ønskede at købe hans maleri. Géricault signerede nådigt værket.

6. Den fantastiske historie om tømmerflåden fra Medusa er i korthed: I 1816 gik fregatten La Méduse i stille vejr på grund ud for Senegal, fransk koloni. Skibet medførte kolonister, soldater og videnskabsmænd, der skulle deltage i en ekspedition. Grundst $\varnothing$ dningen skyldtes dårligt sømandskab, der faldt tilbage på kaptajnen, en inkompetent aristokrat indsat af Bourbon-regeringen. To dage senere måtte skibet forlades, og efter at kaptajnen og de fleste af officererne i fejhed og klassehovmod havde skaffet sig plads i redningsbådene, blev 150 af de ialt 400 ombordværende stuvet sammen på en tømmerflåde, der $\mathrm{i}$ hast var tømret sammen. De heldige $\mathrm{i}$ redningsbådene lovede at tage tømmerflåden på slæb, et løfte, der snart skulle brydes. Allerede den første nat døde mere end 10 . Den følgende nat drak soldater og sømænd sig i fortvivlelse sanseløst berusede og gik til angreb på de officerer, der delte skæbne med dem, et mytteri, der blodigt blev slået tilbage. Den næste morgen kunne man tælle 65 døde. Sulten havde nu fået sit tag, og mange kastede sig over ligene. Skibslægen Henri Savigny, der allerede to måneder efter redningen skulle offentliggøre sin beretning i Joumal des Débats, få dage senere oversat i sin helhed i The Times, skriver: »En stor del af os afslog først at røre den frygtelige føde; men til sidst...så vi i dette skrækkelige måltid vores 
eneste beklagelige middel til at forlænge livet; og jeg foreslog... at vi skulle tørre disse blødende lemmer for at gøre dem mere udholdige for smagen.« Den følgende dag tog de alle del $\mathrm{i}$ måltidet, og da forrådet af vin var sparsomt, måtte de skibbrudne spæde op med havvand og urin. På sjettedagen var der kun 28 tilbage, og da de 13 heraf havde mistet forstanden af smerte og nød, besluttede de фvrige at kaste dem $i$ havet for at spare på rationerne: »...de havde krav på deres del af rationerne og kunne inden de døde konsumere fyrre flasker vin...Tre sømænd og en soldat påtog sig denne grumme henrettelse. Vi vendte vore øjne bort og udgød blodige tårer over disse ulykkelige menneskers skæbne...« Efter 13 dage var dette eksperiment "survival of the fittest « til ende. De 15 blev reddet, men endnu fem måtte snart følge de 135 .

Jeg vil ikke gå nærmere ind på de implikationer i denne beretning, ej heller på Géricaults berømte billede, der påkalder sig sin egen udførlige analyse. Blot skal nævnes, at billedet i realiteten er en syntetisering, en fuld udarbejdning af hele forløbet på tømmerflåden. Det indoptager tematiseringer fra adskillige udkast og også afsluttede billeder, udført i forskellige teknikker: mytteriet, redningen og kannabalismen, sidstnævne i en rædselsvækkende, redningsløs fremstilling i sortkridt, lavering og gouache.

Le Radeau de la Méduse er i kæmpeformat, $491 \times 716 \mathrm{~cm}$, og i denne panoramaet og dioramaets tidsalder så en engelsk impressario mulighederne

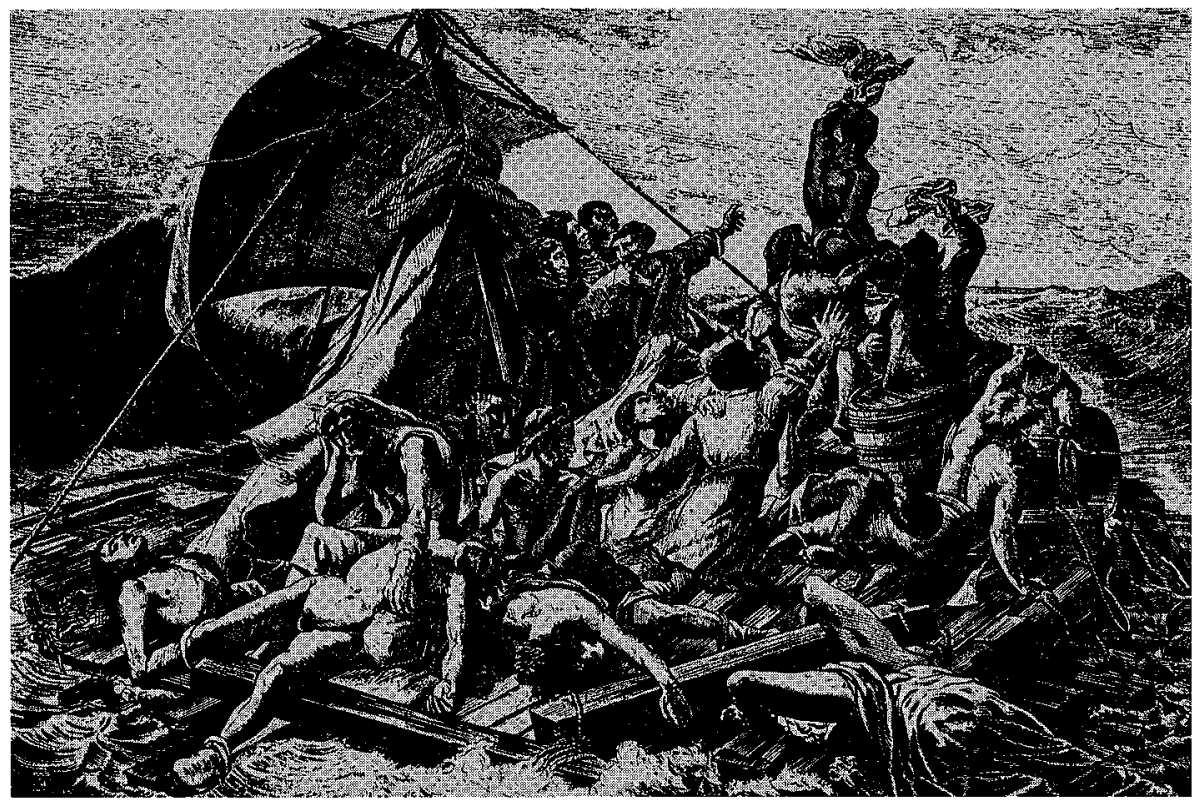

i at udstille billedet for det store publikum. Maleriet blev i 1820 i »Egyptian Hall« p̊̊ Picadilly i London set af 50.000, vel at mærke betalende, besøgende, der fik stukket et sjusket litografi $i$ hånden. Formedelst en ekstra sixpence 
kunne de erhverve sig en 15 siders beskrivelse af dramaet. Géricault indkasserede mellem 17.000 og 20.000 francs, en efter datidens målestok meget stor sum. Ved en senere forevisning i Dublin blev billedet dog udkonkurreret af et Marine Peristrephic Panorama of the Medusa, et 10.000 kvadratfod stort lærred, der garneret med lys- og farveefekter og under orkestral afspilning af en art søstykker rullede forbi. Tømmerflåden drev videre med en lignende symbolværdi som Titanic i dag.

7. De franske dandyer blev kaldt lions, de engelske tigers, alts̊̊ Paris Lions and London Tigers, titlen på ex-kurtisanen Harriet Wilson's bog fra 1825.

8. Uagtet at Georget placerede galskabens sæde i hjernen, var han af den opfattelse, at den ikke primært var organisk betinget, men udløst af faktorer af social og politisk art, der var særegne for de moderne samfund. Netop i det mest udviklede land, England, rammer den ryggesløse konsumption, ørkesløshed $\mathrm{og}$ sanseforfaldenhed, som rigdommen avler, de formuende selv $\mathrm{i}$ form af patologiske symptomer, der opfanger og potenserer et samlet fysisk, psykisk og moralsk forfald. I samme bevægelse går også fattige under i en sjælelig nød, der er en refleks af rigdomsophobningen selv. Bestemte samfundsmæssige former manifesterer sig ødelæggende som en ubestemt lede ved livet. Georget skriver: »selvmordet efter moden overvejelse, englændernes spleen, optræder sædvanligvis $i$ alderen fra 35 til 45 år hos personer, som har udtømt alle livets nydelser, eller som efter at have opnået en vis velstand gennem et virksomt liv bliver lediggængere for at nyde frugterne. Mangelen på moralske idealer, hvilken fører til ateisme, til materialisme, til foragt for tilværelsen, giver i høj grad denne tendens næring. Spleen optræder meget hyppigere i England end i Frankrig: dette skyldes flere årsager. Hos englænderne er der et lidet antal betragtelige formuer og millioner af ulykkelige, der er henvist til tiggeri, to ekstremer, som bevæger sig mod samme mål, lede ved tilværelsen; de store og hasarderede handelsspekulationer må nødvendigvis ofte ophidse sindsbevægelser, der er mere eller mindre skadelige; endelig må umoralen, udskejelserne, der er så almindelige hos dem, især i de højere klasser, til sidst fornedre sjælen og opslide kroppen og således drive mennesker til at gøre ende på dage, som nu kun er en pine...De syge, der er trætte af alt, flygter fra samfundet, trækker sig tilbage i ensomhed, giver deres ideer frit $\emptyset \emptyset \mathrm{b}$ og ender til sidst med at ødelægge sig selv, hvis lægevidenskaben ikke kommer dem til hjælp.« (E. Georget: De la folie. Textes choisis et présentés par J. Postel, Toulouse 1972, p.51).

9. Esquirol udtalte bl.a. dette i sagen Cornier, hvor han var indkaldt som sagkyndig. (Jfr. Georget: „Discussion médico-légale sur la folie ou aliénation mentale«, II. article. Archives Générales de Médicine, T.XI. 1826, pp.518 \& 527.) Henriette Cornier blev idømt livsvarigt tvangsarbejde. I sin pine fandt juryen hende skyldig i drab, begået med forsæt eller fri vilje, men svarede på rettens følgende spørgsmål, at drabet var uoverlagt. Dette mærkelige kompromis mellem anklagemyndighedens og forsvarets synspunkter, mellem forbrydelsen som fri viljesbeslutning $\mathrm{og}$ forbrydelsen som resultat af en indre 
tvang, reddede la fille Comier fra guillotinen.

10. Jules Michelet: L'Étudiant, (1877) Paris 1970, p.110. En sætning flyttet. I julimonarkiets sidste fase, få dage før denne forelæsning, hvorfra passagen er hentet, skulle være holdt, tvang regeringen Michelet til at afbryde sin forelæsningsrække på Collège de France. Michelet lod sammendrag af de forelæsninger, som af politiske grunde ikke kunne afholdes, udkomme i hæfter. Forelæsningerne er i realiteten politiske pamfletter, hvor Michelet oparbejder aspekter af den franske historiske og kunsthistoriske udvikling for herigennem at levere intellektuelt og emotionelt materiale til, hvad han forstår som folkets eminent franske kamp mod monarkiet. På et tidspunkt, hvor interessen for og forståelsen af Géricault var beskeden, ser Michelet Géricault som den første kunstner, der gør sig fri af David-traditionen, den første moderne maler i Frankrig. Netop hans modernitet, hans opgør med det udlevede og forstenede, gør Géricault til våbenfælle i den forestående kamp.

Om Michelets ejendommelige dødsunivers, se Roland Barthes' enestående Michelet, Paris 1954.

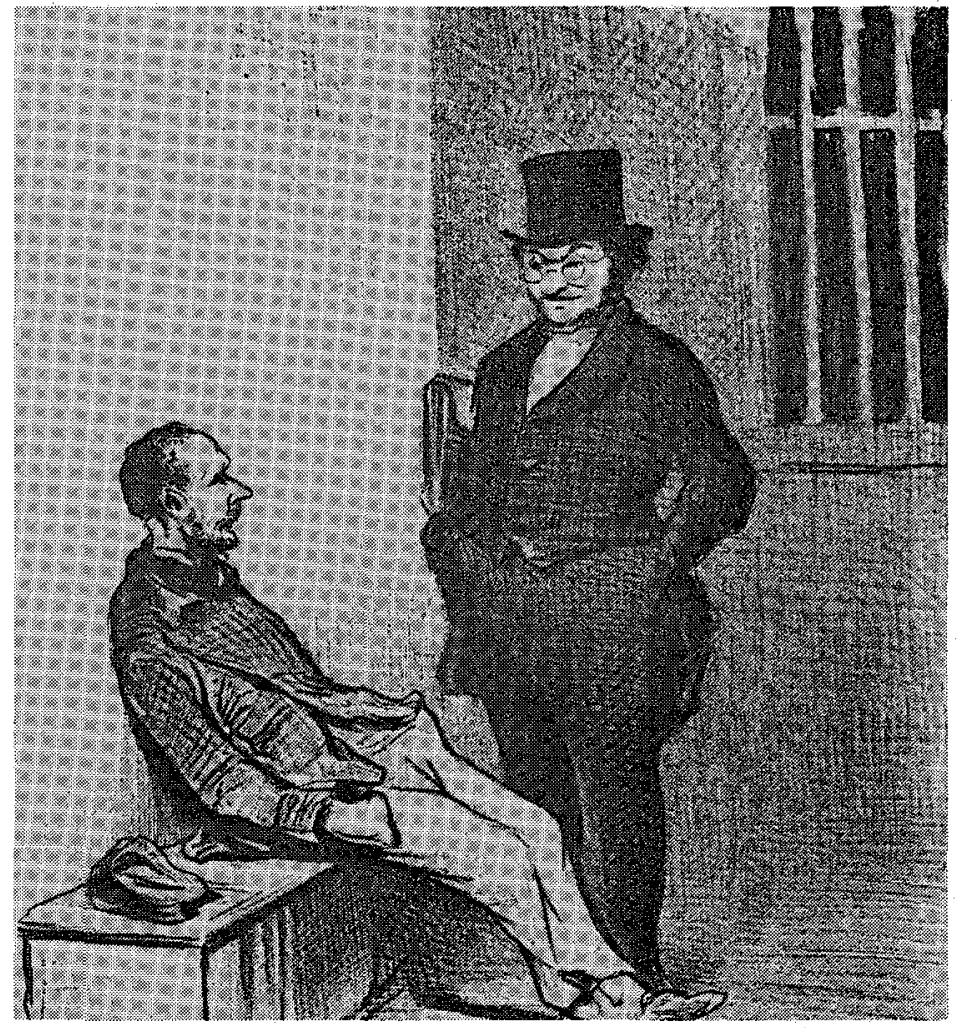

- Det, der bekymrer mig, er, at jeg er anklaget for tolv tyverier!

- Ser man det. Tolv...så meget desto bedre...jeg plæderer for monomani!...

(Daumier) 